\title{
First record of Helobdella hyalina (Hirudinea; Glossiphoniidae) in the mantle cavity of Planorbidae from lentic environments in a Buenos Aires province, Argentina
}

\author{
Negrete, $L H^{\mathrm{a}}$, Gullo, $B S^{\mathrm{b} *}$ and Martín, $S M^{\mathrm{c} *}$

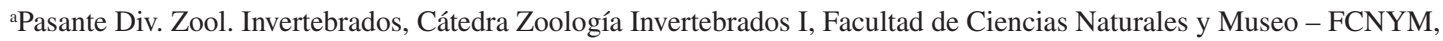 \\ Universidad Nacional de La Plata - UNLP \\ ${ }^{\mathrm{b}}$ Cátedra Zoología Invertebrados I, FCNYM, Universidad Nacional de La Plata - UNLP

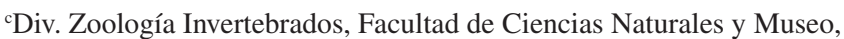 \\ Universidad Nacional de La Plata, Investigador Comisión de Investigaciones Científicas de la Provincia de Buenos Aires, \\ Paseo del Bosque, s/n, 1900 La Plata, Buenos Aires, Argentina \\ *e-mail: bgullo@fcnym.unlp.edu.ar, smartin@fcnym.unlp.edu.ar
}

Received May, 25, 2005 - Accepted November, 8, 2005 - Distributed May, 31, 2007

\section{Introduction}

Biomphalaria peregrina (D'Orbigny, 1835) and Drepanotrema kermatoides (D'Orbigny, 1835) were first reported as hosts of Helobdella hyalina Ringuelet, 1942. Both are important species from the Río de La Plata river basin in Argentina. They are associated with macrophytes of lentic or semilentic environments. They are more frequently observed in semipermanent low-depth environments with vegetation and abundant organic matter (Bonetto et al., 1990).

Freshwater gastropods provide a suitable microhabitat for a wide range of organisms to settle: algae, protozoans, platyhelminthes, nematodes, rotifera, oligochaetes, hirudinea, diptera: chironomids and acari (Di Persia and Radici de Cura, 1973).

Several species of hirudinea Glossiphoniidae are, occasionally or permanently, present in these mollusks having trophic and non - trophic relationships with them (Ringuelet, 1985).

Helobdella Blanchard, 1896 comprises the largest number of species in the Neotropical region and in Argentina including 21 species and subspecies (Ringuelet, 1943; 1944a; 1944b; 1945). Apparently, the centre distribution is in South America. They feed on mollusks, insect larvae and oligochaetes.

Sarah (1971) cited the leech $H$. lineata associated with Helisoma trivolvis (Say, 1817) and Helisoma anceps (Menke, 1830), though the author failed to find them in the mantle cavity.

Klemm (1975a; 1975b; 1976) mentions that two genus of Glossiphoniidae from North America, Glossiphonia and Helobdella, include species that are associated with mollusks and with other invertebrates. For H. lineata (Verril, 1874), the author cited Australorbis glabratus, Helisoma anceps, H. campanulatum, H. trivolvis (Planorbidae), Lymnaea stagnalis and Stagnicola reflexa (Lymanaeidae), Physa gyrina, $P$. integra P. parkeri (Physiidae); in Bivalvia, he mentions Pisidium virginicum as a possible host. On the other hand, H. papillata, a North American species, is associated with the following gastropods: Helisoma anceps,
H. campanulatum, H. trivovlis (Planorbidae); P. parkeri (Physiidae) and Stagnicola elodes, Bulinmnea megasoma (Lymnaeidae). H. punctatalineata Moore, 1939, a species distributed in Puerto Rico, the Dominican Republic and the United States was found in Australorbis glabratus, Planorbis corneus (Planorbidae) and Stenophysa marmorata (Physiidae).With a cosmopolitan distribution except for Australia, H. stagnalis (Linnaeus, 1758) is associated with Physa gyrina, P. integra (Physiidae); Planorbis albus (Planorbidae); Psidium sp. and Sphaerium transversum (Bivalvia; Sphaeriidae).

Ringuelet (1985) cited several leeches associated with mollusks, among them the author mentions $H$. adiastola Ringuelet, 1972 (Diplodon hylaeus and P. insularum) and H. lineata (P. canaliculata and Diplodon delodontus). Helobdella ampullariae Ringuelet, 1945 is the only hirudinea, which is permanently associated with the mantle cavity of Pomella (Pomella) megastoma Gray, 1947.

Damborenea and Gullo (1996) found six species of hirudinea in the mantle cavity of $P$. canaliculata; among the species present, $H$. ampullariae proved to be the dominant species, followed by $H$. triserialis nigricans Ringuelet, 1968, H. simplex (Moore, 1911), H. adiastola, Ringuelet, 1972, H. lineata and H. michaelseni, Blanchard, 1900. H. ampullariae is permanently associated with the mantle cavity of $P$. canaliculata.

\section{Materials and Methods}

Specimens of Biomphalaria peregrina and Drepanotrema kermatoides (Planorbidae) were collected in permanently inundated areas or in those which are subjected to periodic inundations near the Lujan river, in the Reserva de Uso Multiple Otamendi (34 ${ }^{\circ} 17^{\prime} \mathrm{S}$ and $\left.58^{\circ} 53^{\prime} \mathrm{W}\right)$, Campana, Buenos Aires, Argentina.

Sampling was carried out during October, 2002 in the inundated areas where the espartillar community is composed of the totally dominant species Spartina densiflora, and aquatic vegetation such as Bacopa monnieri and Ludwigia peploides. 
Planorbidae were anaesthetised with $0.01 \mathrm{~g}$ Nembutal and then fixed in phormol 5\%. The hirudinea found in the mantle cavity were separated and assigned a specific level, determining if they were carrying eggs or young.

\section{Results}

Two hundred and sixty one specimens of D. kermatoides were examined, only one of them had a specimen of $H$. hyalina (prevalence: $0.38 \%$ ). In addition, two hundred and twelve specimens of $B$. peregrina were analysed revealing 6 specimens of $H$. hyalina (prevalence: $2.35 \%$ ); in only one case, two specimens of $H$. hyalina were found in only one snail.

\section{Conclusion and Discussion}

Helobdella hyalina has a specialised type of leech predation in which a proboscis sucks up body fluids and soft parts of an invertebrate prey organism.

Many of the most common glossiphoniid leeches, such as Glossiphonia complanata and Helobdella stagnalis, are liquidostomatophagous, and feed exclusively upon small bentic invertebrates, primarily small oligochaetes, chironomid larvae and mollusks (Sawyer, 1986).

$H$. hyalina appears to be an opportunistic species that have a trophic relationship with its host this is corroborated by the small number of hosts with leeches. This would suggest that the diet of H. hyalina is based on a variety of food items, including planorbids.

Further surveys must be carried out in order to determine if this kind of relationship is temporary or permanent and to establish if this relationship is exclusively trophic.

\section{References}

BONETTO, AA., RUMI A. and TASSARA MP., 1990. Notas sobre el conocimiento limnológico de los Gasterópodos Paranenses y sus relaciones tróficas. II. Planorbidae, con aspectos distribucionales y sanitarios. Ecosur, vol. 16, no. 27, p. 69-84.

DAMBORENEA, MC. and GULLO, BS., 1996. Hirudíneos asociados a la cavidad paleal de Pomacea canaliculata (Lamarck, 1822) (Gastropoda:Ampullariidae) del balneario Bagliardi, Río de la Plata, Argentina. Neotrópica, vol. 42, no. $107-108$, p. $97-101$.

DI PERSIA, DH. and RADICI DE CURA, MS., 1973. Algunas consideraciones acerca de los organismos epibiontes desarrollados sobre Ampullariidae. Physis B, vol. 32, no. 85, p. 309-319.

KLEMM, DJ., 1975a. Studies on the feeding relationships of leeches (Annelida: Hirudinea) as natural associates of mollusks. Sterkiana, no. 58, p. 1-50.

-, 1975b. Studies on the feeding relationships of leeches (Annelida: Hirudinea) as natural associates of mollusks. Sterkiana, no. 59, p. 1-20

-, 1976. Leeches (Annelida: Hirudinea) found in North American Mollusks. Malacol. Rev., vol. 9, no. 1/2, p. 63-76.

RINGUELET, RA., 1943. Sobre la morfología y variabilidad de Helobdella triserialis (Em. Bl.) (Hirudinea, Glossiphoniidae). Notas del Museo de La Plata (Zool.), vol. 8, no. 69, p. 205-240.

-, 1944a. Sinopsis sistemática y zoogeográfica de los Hirudíneos de la Argentina, Brasil, Chile, Paraguay y Uruguay. Rev. Mus. de La Plata. N. s. (Zool.), vol. 3, no. 22, p.163-232.

-, 1944b. Revisión de los Hirudíneos Argentinos de los géneros Helobdella R. B1., Batracobdella Vig., Cylicobdella Gr. y Semiscolex Kinb. Rev. Mus. de La Plata. N. s. (Zool.), vol. 4, no. 25 , p. $5-93$.

-, 1945. Hirudíneos del Museo de La Plata. Rev. Mus. de La Plata. N. s (Zool.), vol. 4, no. 26, p. 95-137.

-, 1985. Annulata Hirudinea. En Castellanos, Z. (Dir). Fauna De Agua Dulce De La República Argentina, FECIC, vol. 27, no. 1. Bs. As., 321p.

SARAH, HH., 1971. Leeches found in two species of Helisoma from Fleming's Creek, Michigan. Ohio, J. Sci., vol. 71, no. 1, p. 15-20.

SAWYER, RT, 1986. Leech Biology and Behaviour. Feeding Biology, Ecology and Sistematics. Oxford University Press, New York, vol. 2, 809p. 